\title{
分葉状頸管腺過形成の術前診断で腹腔鏡下手術を施行し、 術後に子宮頸部胃型粘液性癌と診断した2例
}

市立貝塚病院 産婦人科

甲村奈緒子、直居裕和、市川冬輝、田中あすか、 小笹勝巳、増田公美、大塚博文、横井 猛

\section{Gastric-type adenocarcinoma of the uterine cervix diagnosed after laparoscopic surgery following preoperative diagnosis of lobulated cervical gland hyperplasia: A report of two cases}

Naoko Komura, Hirokazu Naoi, Fuyuki Ichikawa, Asuka Tanaka,

Katsumi Kozasa, Kumi Masuda, Hirofumi Otsuka, Takeshi Yokoi

Department of Obstetrics and Gynecology, Kaizuka City Hospital, Japan

\begin{abstract}
Most cystic lesions of the uterine cervix are benign; however, it is important to distinguish these from gastric-type adenocarcinoma, including minimal deviation adenocarcinoma. Although radical hysterectomy is the standard surgical procedure for cervical cancer, it is highly invasive and requires accurate preoperative diagnosis. We report two cases of gastric-type adenocarcinoma of the uterine cervix in patients who were preoperatively diagnosed with lobular endocervical glandular hyperplasia (LEGH) and underwent laparoscopic simple hysterectomy. These cases highlight the role of preoperative conization for cervical cystic lesions. Additionally, definitive diagnosis is difficult in patients with preoperative imaging findings showing LEGH; therefore, laparoscopic surgery should be carefully considered if malignancy cannot be ruled out. Gastric-type adenocarcinoma of the uterine cervix is rare, and a limited number of cases could be investigated at a single center; therefore, further multicenter large-scale studies are warranted to confirm our findings.
\end{abstract}

Key words: Minimal deviation adenocarcinoma, Lobular endocervical glandular hyperplasia, laparoscopic surgery

\section{【緒 言】}

子宮頸部胃型粘液性癌は、欧米では子宮頸部腺 癌全体の $2-5 \%$ を占めるのに対して、わが国で は20-25\%を占め、早期に遠隔転移や腹膜播種を 呈し予後不良な疾患である ${ }^{1)}$ 。2014年に改訂され たWHO組織分類（第 4 版）に、子宮頸部腺癌の 亜型である胃型腺癌（gastric type）が追加され、 「胃型の分化を示す粘液性腺癌」と定義されてい る ${ }^{2)}$ 。その中で最小偏倚腺癌 (minimal deviation adenocarcinoma : MDA）は、悪性腺腫 (adenoma malignum）と同義語で、超高分化型の胃型腺癌 と分類されている。組織学的には、「細胞質が極 めて豊富で淡明ないし淡好酸性」で「細胞境界が 明瞭」な粘液性腺癌として定義される。臨床的に は、水様性帯下を症状として認めることが多く、 経腟超音波検査では子宮頸部の囊胞状病変を特徵 とする。一方、分葉状頸管腺過形成 (lobular endocervical glandular hyperplasia: LEGH) は、 1999年にNucciらにより提唱された疾患概念で、 
形態的にMDAを含む胃型粘液性癌と類似するが 良性の経過をとる病変であり、その鑑別が重要で ある ${ }^{3)}$ 。今回我々は術前にLEGH と診断し、腹腔 鏡下単純子宮全摘出術を施行したが、術後に子宮 頸部胃型粘液性癌と診断した 2 例を経験したため 報告する。なお対象となる個人から文書での同意 が得られている。

\section{【症例 1】}

患者：48歳 0 妊, 女性

主訴；水椂性帯下

既往歴：なし

現病歴 ; 水椂性帯下を主訴に前医を受診したとこ ろ、子宮頸部囊胞を認め、精査目的に当院に紹介 受診した。経腟超音波検査では、子宮頸部に多房 性囊胞性病変を認め、子宮体部後壁に $5 \mathrm{~cm}$ 大の 筋層内筋腫を認めた。子宮頸部細胞診はNegative for intraepithelial lesion or malignancy (NILM) で、骨盤MRI検査では、子宮頸部の深部に $28 \mathrm{~mm}$ 大の多房性囊胞性病変を認め、内腔側に細かな囊 胞が集簇しており、外側に大きな囊胞が目立つ、 いわゆる「コスモスサイン」を認めた（図 1 )。 画像所見から子宮筋腫㧍よびLEGHと術前診断 し、子宮筋腫による過多月経を伴うことから、手 術加療の方針とした。全身麻酔下に腹腔鏡下単純 子宮全摘出術・両側卵管切除術を行い、経腟的に 回収した。手術時間は 1 時間56分、出血量は少量 であった。術後の病理診断では、淡好酸性かつ円 柱状の細胞質を有する異型腺管を認め、頸部筋層

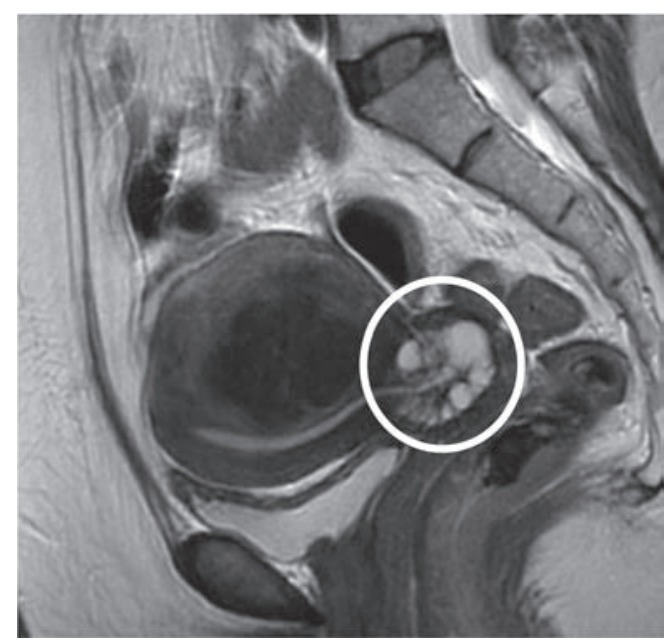

a

図 1. 症例 1 骨盤MRI所見

a: T2強調像 (矢状断) 、 b: T2強調像 (水平断) 子宮頸部の深部に28mm大の囊胞性病変を認めた。（円）
深部まで進展していた（図 2)。異型腺管は子宮 壁の深部に達する浸潤を示し、水平方向の広がり は34mmであり、子宮頸部胃型粘液性癌（Minimal deviation adenocarcinoma/adenoma malignum) IB1期（FIGO2008）と診断した。脈管侵襲や、腟 壁浸潤、子宮傍組織浸潤は認めなかった。深い頸 部間質浸潤を認め、本来標準術式としては広汎子 宮全摘出術が必要なところを単純子宮全摘出術と なったことを考慮し、術後補助療法として同時化 学放射線療法 (concurrent chemoradiotherapy: CCRT) (weekly CDDP $40 \mathrm{mg} / \mathrm{m}^{2} \times 6$ cycles, RT $50.4 \mathrm{~Gy} / 28 \mathrm{Fr}$ ) を行った。治療後 1 年 8 カ月が経 過し、再発を認めていない。

\section{【症例2】}

患者 : 46 歳 0 妊, 女性

主訴；過多月経、水様性帯下

既往歴：なし

現病歴; 過多月経・水様性帯下を主訴に前医を受 診したところ、子宮頸部腫瘤・子宮筋腫を認め、 精查目的に当院に紹介受診した。性交涉歴がない ため経腹超音波検查を施行したところ、子宮頸部 に囊胞性病変を認め、子宮内膜は $20 \mathrm{~mm}$ に肥厚し ていた。骨盤MRI検査では、子宮頸部の深部に $20 \mathrm{~mm}$ 大の細かな囊胞が集簇した病変を認め、ま た子宮体部に $35 \mathrm{~mm}$ 大の腫瘤㧍よび $30 \mathrm{~mm}$ 大まで の多発子宮筋腫を認めた（図 3 )。静脈麻酔下に 行った子宮頸部細胞診はNILMで、子宮内膜全面 掻爬術では異型のない内膜増殖症を伴う子宮内膜

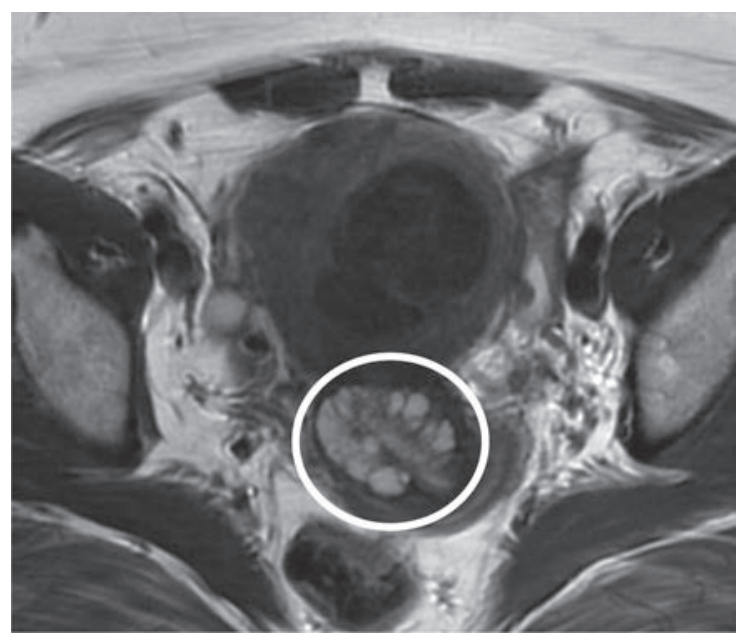

b 


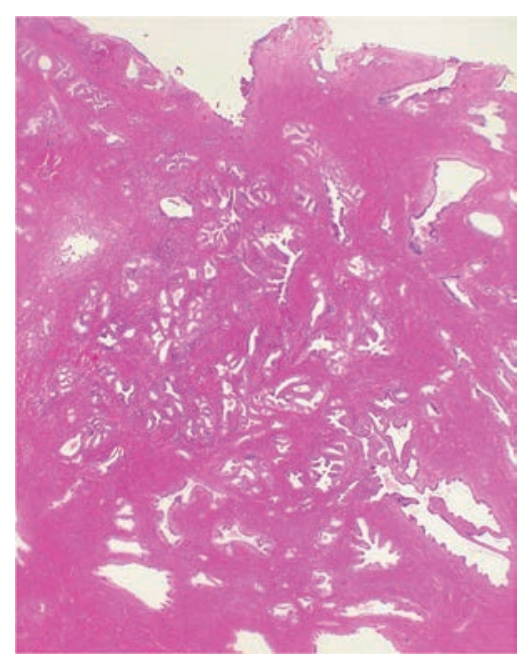

a

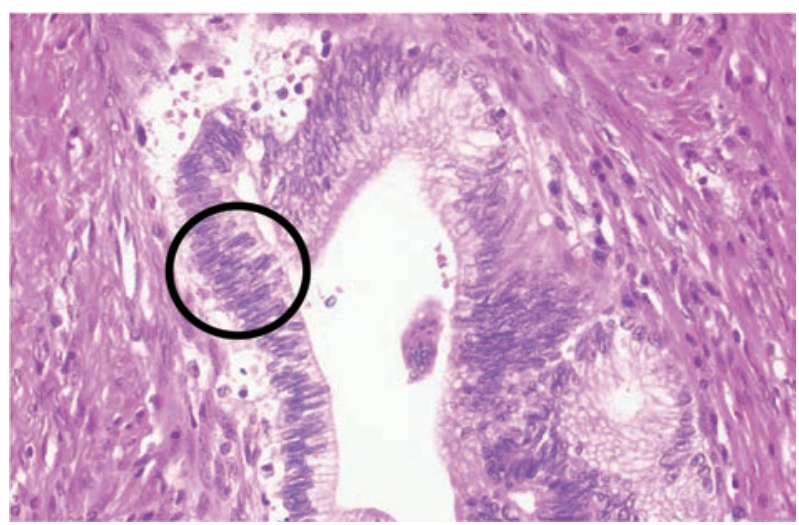

b

図2.症例 1 病理組織学的所見

a: HE染色 (x4) 異型腺管が頸部筋層深部まで進展する。 b: HE染色 (x400) 核の重積を認める (円)。

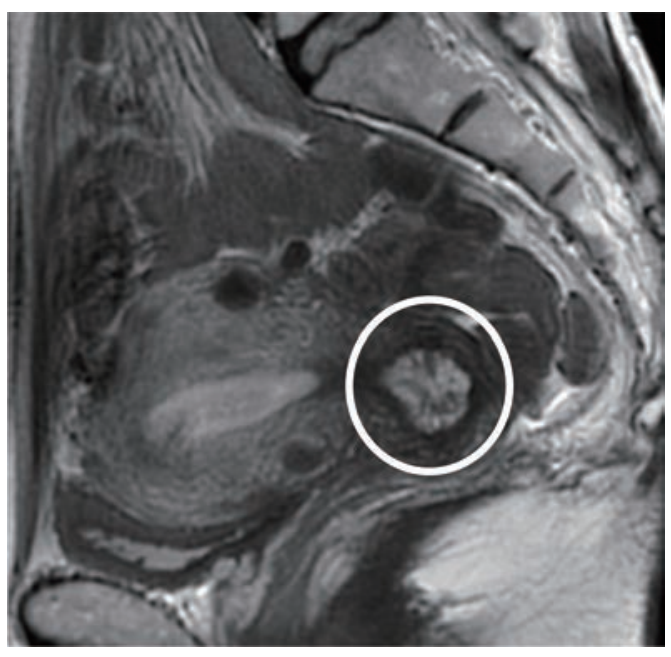

a

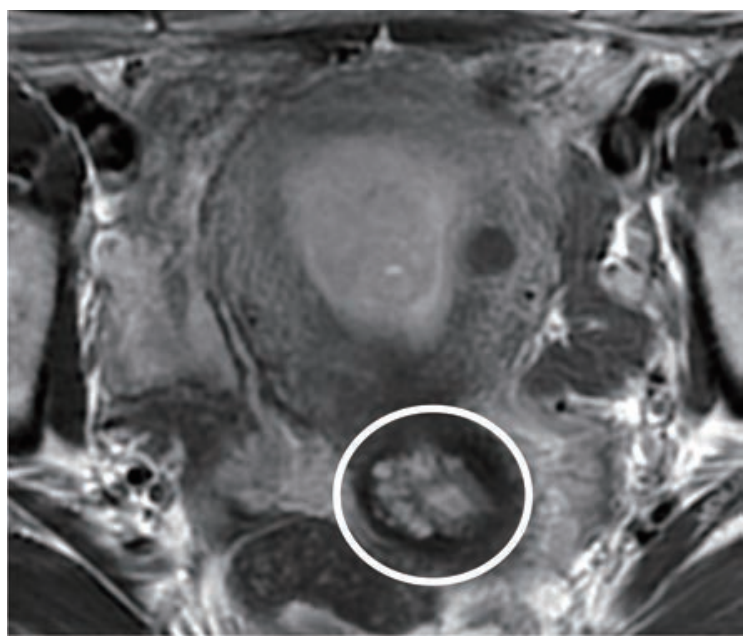

b

図3. 症例 2 骨盤MRI所見

$a: T 2$ 強調像 (矢状断)、 b: T2強調像（水平断）

子宮頸部の深部に20mm大の細かな囊胞が集簇した病変を認めた（円）。

ポリープとの診断であった。LEGHおよび子宮内 膜ポリープ、多発子宮筋腫と術前診断し、子宮内 膜ポリープによる過多月経およびLEGHに伴う水 様性帯下を伴うことから、手術加療の方針とした。 全身麻酔下に腹腔鏡下単純子宮全摘出術 - 両側卵 管切除術を行い、経腟的に回収した。手術時間は 2 時間12分、出血量は少量であった。術後の病理 診断では、頸部筋層に異型腺管を認めた。それら の腺管は類円形の核小体明瞭な核を有する細胞質 好酸性の高円柱上皮細胞に裏装され、小型の分葉 状もしくは分岐構造を伴いながら頸部筋層媣部ま
で進展していた（図 4)。以上より、子宮頸部胃 型粘液性癌 (Minimal deviation adenocarcinoma/ adenoma malignum）と診断し、浸潤部の水平方 向の広がりが $15 \mathrm{~mm}$ であるこから IB1 期 （FIGO2008）と診断した。脈管侵襲や、胵壁浸潤、 子宮傍組織浸潤は認めなかった。その他、子宮体 部では平滑筋腫や、異型のない内膜増殖症を局所 性に伴う内膜ポリープを認めた。媣い頸部間質浸 潤を認め、症例1と同様に、術後補助療法として CCRT (weekly CDDP $40 \mathrm{mg} / \mathrm{m}^{2} \times 6$ cycles, RT $50.4 \mathrm{~Gy} / 28 \mathrm{Fr}$ ）を行った。治療後 1 年 2 カ月が経 


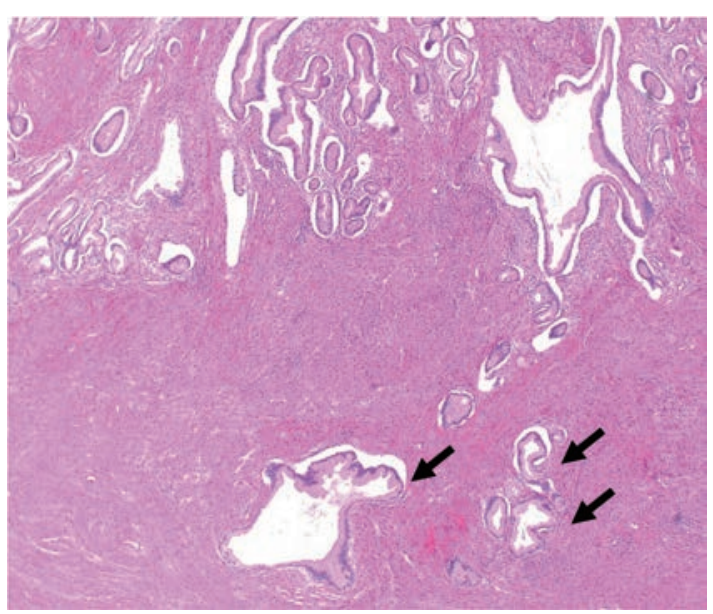

a

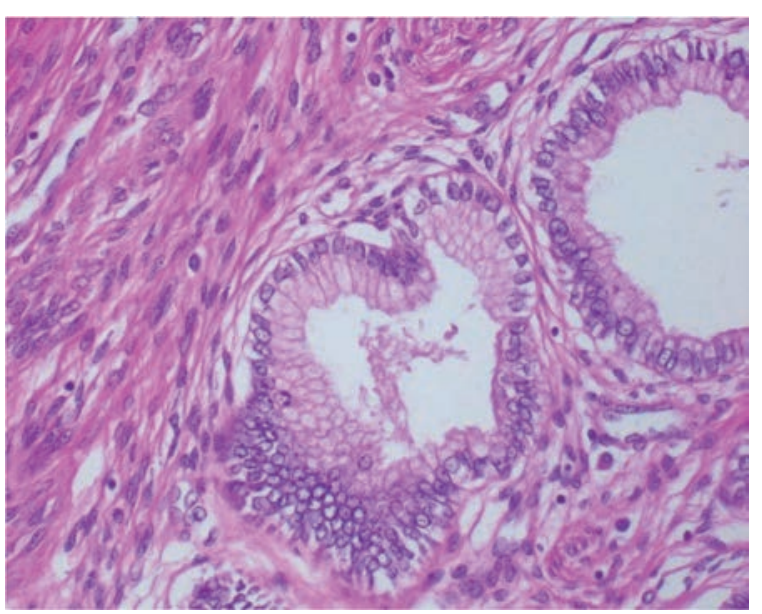

b

図 4. 症例 2 病理組織学的所見

a: $\mathrm{HE}$ 染色 (x4) 複雑な屈曲を伴う腫瘍腺管が頸部筋層深層まで進展する (矢印)。

b: HE染色（x400）類円形の核小体明瞭な核を有する細胞質好酸性の高円柱上皮細胞に裏装された異型腺管を認める。

過し、再発を認めていない。

\section{【考察】}

子宮頸部囊胞性病変は、そのほとんどが良性疾 患でありナボット襄胞、トンネルクラスター、 LEGH、微小腺管過形成、非特異的過形成が鑑別 に挙げられるが、頻度は低いもののMDAを含む 子宮頸部胃型粘液性癌などの悪性疾患の可能性も 考慮すべきである。

子宮頸部胃型粘液性癌は、40歳代に好発し、 80\%が高分化型で、HPV非依存性であることが知 られている ${ }^{4)}$ 。水様性帯下や子宮頸部の囊胞性病 変を特徵とし、早期に浸潤・転移を起こし、予後 不良な疾患である。子宮頸部胃型粘液性癌の予後 を検討した報告では、 5 年生存率は通常型の子宮 頸部腺癌が91\%であるのに比べ、胃型粘液性癌で は $42 \%$ と極めて予後不良な疾患だと報告してい $ろ^{5)}$ 。特に、子宮頸部胃型粘液性癌と臨床上・組 織学的にも類似している良性疾患であるLEGHと の鑑別が臨床上重要である。

子宮頸部胃型粘液性癌とLEGHの鑑別方法とし て、頸管細胞診、画像検査が術前診断に有用であ るとされる ${ }^{6)}$ 。子宮頸部胃型粘液性癌では、術前 頸管細胞診でAGC-FN、AIS、Adenocarcinoma などの異常が認められる場合があるとの報告があ $\eta^{6)}$ 、AGC-FN以上は悪性を十分に視野に入れて 手術を行う必要がある。本 2 症例では、子宮頸部 細胞診は行ったが、頸管組織診（頸管内膜择爬） は術前に行っておらず、術前に十分な検討が必要 であったと考えられる。ただし、術前の細胞診や
組織診単独での診断率は高くなく、画像検査など の結果も考慮して鑑別する必要がある。

画像検査では、骨盤MRI検査が有用である ${ }^{6.7)}$ 。 ナボット襄胞では、境界明瞭な中型から大型の囊 胞性病変を認め、充実成分は認めないのに対して、 LEGHは子宮頸部に中心部に微小な集簇や充実部 を示し、辺縁部に粗大な囊胞が配列する「コスモ スサイン」を呈することが多い。子宮頸部胃型粘 液性癌では、病変の境界が不明瞭で、充実部の存 在を特徵とする。症例1では、内腔側に細かな囊 胞が集簇しており、外側に大きな霊胞が目立つ、 いわゆる「コスモスサイン」を認め、症例 2 では、 細かな囊胞が集簇しており、また内部に充実部分 を認めなかったことから、いずれの症例において も、子宮頸部胃型粘液性癌に特徽的な所見は認め ず、積極的に悪性と疑わなかった。ただし、近年 のKidoらの報告 ${ }^{8)}$ では、子宮頸部胃型粘液性癌の MRI画像所見として、細かな囊胞が腫瘍内にびま 几性に存在することを報告して扔り、症例 2 にお いては、その画像所見に加え、水様性帯下を伴う 臨床所見を含め考慮すると、術前に胃型腺癌を疑 い得る可能性はあったと考察される。なお、MRI 検査での頸部囊胞性病変の診断精度を調べた過去 の報告では、良性疾患の診断は $86.7 \%$ と比較的高 い結果であったが、悪性症例では $66.7 \%$ 低くな

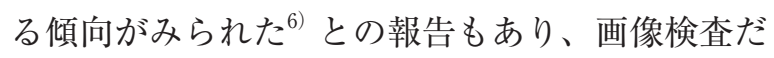
けでは完全に鑑別できない点には留意する必要が ある。

免疫組織化学染色では、胃幽門腺粘液を認識す る抗体であるHIK 1083の陽性率が高い9) が、こ 
の特徵は、ナボット囊胞などの良性病変との鑑別 には有用であるが、LEGHは胃型粘液性癌と同様 に胃型粘液を産生する ${ }^{10)}$ ため、LEGHと胃型粘液 性癌との鑑別には用いられない。HE染色では、 胃型粘液性癌は腺管の複雑な屈曲や分枝、瘉合と いった高度の構造異型および間質への破壊性浸潤 を伴う一方で、LEGHでは拡張した腺管とその周 囲の中型ないし小型の腺管が分葉状に増生するも のの、浸潤性を認めない点が胃型粘液性癌と異な る。

2006 年に日本産科婦人科学会婦人科腫瘍委員会 の研究として「子宮頸部悪性腺腫とその類縁疾患 の術前診断および治療ガイドライン確立にむけた 臨床研究」が行われ、診断と治療の指針の試案が 提案された ${ }^{6)}$ 。研究結果からは、画像検査で子宮 頸部の囊胞性病変を認め、細胞診異常を認める場 合に治療介入することが推奨されているが、それ らの検查で明らかな悪性所見を認めない場合につ いては、定まった見解は述べられていない。症例 1 ・ 2 いずれにおいても、頸部細胞診や画像検查 から術前にLEGHと診断し、単純子宮全摘出術を 行ったが、先に術前診断目的として子宮頸部円錐 切除術を行うべきであったと考えられた。 Takatsuらは子宮頸部囊胞性病変に対して子宮摘 出を行った症例で術前に円錐切除を行った13例の うち、12例で円錐切除の診断が摘出子宮による最 終診断と一致したと報告し、円錐切除術は最終診 断に対する一つの目安になる可能性があると述べ ている ${ }^{6)}$ 。ただし、円錐切除術を行っても、最も 異型の強い部位を摘出できない可能性もある点に は留意が必要である。

LEGHが疑われる症例に対する治療として、子 宮頸部悪性疾患に準じて広沉あるいは準広汎子宮 全摘出術を行うべきか、それとも単純子宮全摘出 術を行うのか、標準術式として定まった見解はな い。本症例のように、腹腔鏡下手術も許容される と考えられるが、悪性を念頭に置く場合には近年 報告されたLACC試験の結果を考慮し、腹腔鏡下 手術の選択は慎重に行うべきであると考える。 LACC試験は、早期子宮頸癌に対する低侵襲広汎 子宮全摘出術と開腹広汎子宮全摘出術を行った症 例を比較した多施設前向き試験であり、開腹群と 比較し低侵襲群では、無病生存率および全生存率 が低い結果であった ${ }^{11)}$ 。低侵襲群で局所再発が多 く認められた点からは、腹腔鏡下手術では、腹腔 内に腫瘍が暴露や散布されることがないように、 腟管の切開や子宮の摘出方法に十分留意する必要
があると言える。本症例では、2例ともに子宮マ ニピュレーターを留置しており、また回収の際に は回収袋を使用していなかった。今回のように、 子宮頸部に囊胞性病変を認め、ナボット襄胞など の明らかな良性疾患を疑う場合以外の症例では、 MDAなどの胃型粘液性癌の可能性も考慮し、子 宮マニピュレーターは留置せず、また回収の際に は回収袋を用いた方が、腫瘍散布予防の観点から は有効であった可能性が高い。

また一般的に、良性疾患として単純子宮全摘出 術が施行され、術後に子宮頸癌IB期またはそれ 以上と診断された症例に対する取扱いについて、 子宮頸癌治療ガイドライン（2017年）では、放射 線治療 (radiation therapy: RT) あるいはCCRT の追加が考慮されるとしている (グレードC1 $)^{12)}$ 。 特に、腫瘍径の大きい症例や脈管侵襲を示す症例 などでは予後が不良であり、高リスク症例につい ては、CCRTが推奨されている。症例 1 ・ 2 にお いては、子宮頸部胃型粘液性癌IB1期と診断し、 腫瘍径は $4 \mathrm{~cm}$ 未満で、脈管侵襲は認めなかった が、広沉子宮全摘出術を行うべき症例に対して単 純子宮全摘出術を行ったことで局所の切除範囲が 不十分となったこと、リンパ節郭清を行っていな いこと、腫瘍拡散の予防策を取らずに腹腔鏡手術 を行ったことで腫瘍拡散のリスクが生じたことを 考慮し、術後治療としてCCRTを選択した。ただ し、胃型粘液性癌に対する術後補助療法としての CCRTの有効性のまとまった報告はなく、子宮傍 結合組織摘出術 (parametrectomy) や骨盤リン パ節郭清を追加で行う選択肢もあったと考察され る。米国NCCNガイドライン（2019年第 4 版）で は、偶然的に浸潤子宮頸癌が発見された場合には、 画像検查のうえ、切除断端の陽性の有無や、肉眼 および画像上の残存病変の有無により、RTや CCRTまたは、子宮傍結合組織摘出術・上部腟切 除術・骨盤リンパ節郭清術の追加を考虑するとし ている ${ }^{13)}$ 。Parkらは、良性疾患・子宮頸部高度異 形成 - 子宮頸部上皮内腺癌の術前診断で単純子宮 全摘出術を行い、術後に浸潤子宮頸癌との診断を 得たIA2期-IIA期99例に対して、その後経過観察、 RTまたはCCRT、子宮傍結合組織摘出術を行っ た症例を後方視的に比較検討したところ、再発率 は経過観察群では34.6\%、RTまたはCCRT群では 6.8\%、子宮傍結合組織摘出術群では $0 \%$ あった と報告している（観察期間中央值116力月） ${ }^{14)}$ 。さ らに治療後の合併症の頻度は、RTまたは CCRT 群で $27 \%$ 、子宮傍結合組織摘出術群では17\%であ 
り、子宮傍結合組織摘出術はその他の治療と同等 の治療効果をもち、さらに治療後の合併症が少な かったと述べている ${ }^{14)}$ 。ただし、この報告は単施 設での後方視的検討であること、また約 $80 \% に$ 扁 平上皮癌が含まれていることから、本症例にその まま当てはめることはできない。本 2 症例のよう に、術後に子宮頸部胃型粘液性癌と診断され、標 準術式を行えなかった場合の追加治療についてま とまった報告はないことから、術後にRTを追加 するのか、CCRTを追加するのか、もしくは子宮 傍結合組織摘出術や骨盤リンパ節郭清を追加する のかについて、胃型粘液性癌での症例を蓄積し、 再発率や合併症の頻度について比較検討が必要で ある。

また胃型粘液性癌の多くの症例では、胃型粘液 性癌の周辺にLEGHを伴うと近年報告されてい

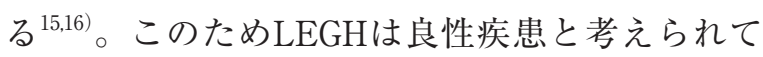
いるが、胃型粘液性癌の前駆病変である可能性も 指摘されている。LEGHから胃型粘液性癌へと悪 性化する過程に打ける異形成ないし上皮内癌的な 中間病変の可能性として、Atypical LEGHの存在 が近年指摘されている ${ }^{17)}$ 。Kobaraらは175例の子 宮頸部囊胞性病変に対して後方視的に検討し、画 像所見と組織所見から69例をLEGHとして経過観 察（平均観察期間57.1力月）を行ったところ、12 例でサイズの増大や細胞診異常などを認めたため 手術を行い、このうち1例にMDA、2 例に

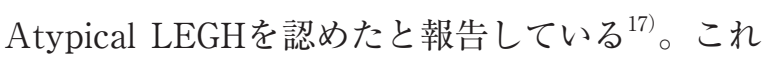
らの結果から、 5 年間の経過観察での悪性化の頻 度は $1.4 \%$ と決して高率ではないものの、LEGHと 考えて経過観察中の症例に対しては、サイズの増 大や細胞診異常などを認める場合に、悪性疾患も 念頭に置き手術を考慮する必要があると言える。

\section{【結語】}

今回、術前にLEGH と診断し腹腔鏡下単純子宮 全摘出術を施行したところ、術後に子宮頸部胃型 粘液性癌と診断した 2 例を経験した。本 2 症例を 通して、子宮頸部囊胞性病変を認める場合には、 術前に円錐切除術を行うべきであったこと、また LEGH様の画像を呈する場合には、確定診断が難 しいため悪性腫瘍を除外できない場合には、腹腔 鏡下手術の選択は慎重に行うべきであると考えら れた。子宮頸部胃型粘液性癌は頻度が低く、単施 設での症例数が限られるため、今後多施設での症 例を蓄積し、さらなる検討が必要である。

$$
\text { すべての著者に開示すべき利益相反はない。 }
$$

\section{【参考文献】}

1) Nishio S, et al: Analysis of gastric-type mucinous carcinoma of the uterine cervix - An aggressive tumor with a poor prognosis: A multi-institutional study. Gynecol Oncol 2019: 153: 13-19.

2. R.J. Kurman, International Agency for Research on Cancer, World Health Organization. WHO Classification of Tumours of Female Reproductive Organs, 4th edition International Agency for Research on Cancer, Lyon, 2014

3 ) Nucci MR, Clement PB, Young RT: Lobular endocervical glandular hyperplasia, not otherwise specified. Am J Surg Pathol 1999: 23: 886-891.

4) Xu JY, et al: Absence of human papillomavirus infection in minimal deviation adenocarcinoma and lobular endocervical glandular hyperplasia. Int J Gynecol Pathol 2005: 24: 296-302.

5 ) Karamurzin YS, et al: Gastric-type Endocervical Adenocarcinoma: An Aggressive Tumor With Unusual Metastatic Patterns and Poor Prognosis. Am J Surg Pathol 2015: 39: 1449-1457.

6 ) Takatsu A, et al: Preoperative differential diagnosis of minimal deviation adenocarcinoma and lobular endocervical glandular hyperplasia of the uterine cervix: a multicenter study of clinicopathology and magnetic resonance imaging findings. Int J Gynecol Cancer 2011: 21: 1287-1296.

7 ) Tsuboyama $T$, et al: A case of gastric-type adenocarcinoma of the uterine cervix associated with lobular endocervical glandular hyperplasia: radiologic-pathologic correlation. Abdom Imaging 2015: 40: 459-465.

8 ) Kido A, et al: Magnetic resonance appearance of gastric-type adenocarcinoma of the uterine cervix in comparison with that of usual-type endocervical adenocarcinoma: a pitfall of newly described unusual subtype of endocervical adenocarcinoma. Int J Gynecol Cancer. 2014: 24: 1474-1479.

9 ) Ota $\mathrm{H}$, et al: Cell lineage specificity of newly raised monoclonal antibodies against gastric mucins in normal, metaplastic, and neoplastic human tissues and their application to pathology diagnosis. Am J Clin Pathol 2001: 115: 69-79.

10) Mikami $Y$, et al: Gastrointestinal immunophenotype in adenocarcinomas of the uterine cervix and related glandular lesions: a possible link between lobular endocervical glandular hyperplasia/pyloric gland metaplasia and 'adenoma malignum'. Mod Pathol 2004: 17: 962-972.

11) Ramirez PT, et al: Minimally Invasive versus Abdominal Radical Hysterectomy for Cervical Cancer. N Engl J Med 2018: 379: 1895-1904. 
12）日本婦人科腫瘍学会：子宮頸がん治療ガイドライン 2017年版：74-75, 金原出版.

13) NCCN : Cervical Cancer NCCN Guidelines Version 4. 2019: https://www2.tri-kobe.org/nccn/guideline/ gynecological/english/cervical.pdf（最終アクセス日 2020年12月27日)

14) Park JY, et al: Management of occult invasive cervical cancer found after simple hysterectomy. Ann Oncol 2010: 21(5): 994-1000.

15) Mikami Y, McCluggage WG: Endocervical glandular lesions exhibiting gastric differentiation: an emerging spectrum of benign, premalignant, and malignant lesions. Adv Anat Pathol 2013: 20: 227 237.

16) Sugihara $T$, et al: Case of minimal deviation adenocarcinoma: possible clinical link to lobular endocervical glandular hyperplasia as its origin. J Obstet Gynaecol Res 2015: 41: 483-487.

17) Kobara H, et al. Limited frequency of malignant change in lobular endocervical glandular hyperplasia. Int J Gynecol Cancer 2020: 30(10): 14801487. 